Mycologia, 103(1), 2011, pp. 195-202. DOI: 10.3852/10-119

(C) 2011 by The Mycological Society of America, Lawrence, KS 66044-8897

\title{
Two new species of Rhynchosporium
}

\author{
Pascal L. Zaffarano \\ Forest Pathology and Dendrology, Institute of Integrative \\ Biology (IBZ), ETH Zürich, 8092 Zürich, Switzerland \\ Bruce A. McDonald \\ Plant Pathology, Institute of Integrative Biology (IBZ), \\ ETH Zürich, 8092 Zürich, Switzerland \\ Celeste C. Linde ${ }^{1}$ \\ Evolution, Ecology and Genetics, Research School of \\ Biology, College of Medicine, Biology and Environment, \\ Building 116, Daley Road, Australian National \\ University, Canberra, ACT 0200, Australia
}

Abstract: Rhynchosporium consists of two species, $R$. secalis and $R$. orthosporum. Both are pathogens of grasses with $R$. secalis infecting a variety of Poaceae hosts and $R$. orthosporum infecting Dactylis glomerata. Phylogenetic analyses of multilocus DNA sequence data on $R$. secalis isolates originating from cultivated barley, rye, triticale and other grasses, including Agropyron spp., Bromus diandrus and Hordeum spp., resolved the monophyletic groups into three species according to their respective hosts. Host specificity according to phylogenetic lineages was confirmed with pathogenicity studies. Because $R$. secalis was described first on rye this name is retained for Rhynchosporium isolates infecting rye and triticale. Rhynchosporium isolates infecting cultivated barley and other Hordeum spp. and Bromus diandrus belong to a distinct species, $R$. commune. Similarly isolates infecting Agropyron spp. represent a distinct species of Rhynchosporium, namely $R$. agropyri. A PCR-RFLP assay was developed as a rapid tool for species identification of $R$. secalis and $R$. commune.

Key words: agriculture, cereal crops, Helotiales, host specialization, infectious diseases, speciation

\section{INTRODUCTION}

Two reported species of the fungal anamorph genus Rhynchosporium infect cereals and grasses. Rhynchosporium secalis (Oudem.) J.J. Davis causes the necrotic disease called scald or leaf blotch on barley, rye, triticale and other Poaceae, especially on species of Hordeum, Agropyron, Bromus and Lolium (Caldwell 1937, Shipton et al. 1974, Welty and Metzger 1996). The first descriptions and designation of the organism (Marsonia secalis) isolated from rye dates to 1897

Submitted 21 Apr 2010; accepted for publication 19 Jul 2010.

${ }^{1}$ Corresponding author. E-mail: celeste.linde@anu.edu.au from the Netherlands by Oudemans (Oudemans 1897). In the same year another description was made in Germany and the fungus was named Rhynchosporium graminicola (Frank 1897). Later both Davis $(1919,1921)$ and Caldwell (1937) proposed the combination of the two names that led to today's generally accepted name of $R$. secalis. It is likely that $R$. secalis is a member of the Helotiales because comparisons of ITS and mating-type DNA sequences showed that the species is closely related to the helotialean plant pathogens Pyrenopeziza brassicae and Oculimacula yallundae (Goodwin 2002, Foster and Fitt 2004). The only other known Rhynchosporium species is $R$. orthosporum, isolated from Dactylis glomerata (Caldwell 1937). Rhynchosporium orthosporum is morphologically different from $R$. secalis because it lacks the typical beaked form of the conidia.

In Zaffarano et al. (2006) we detected significant population genetic evidence for host specialization with RFLP markers. A population originating from a Swiss rye field was genetically differentiated $\left(\mathrm{G}_{\mathrm{ST}}=\right.$ 0.59 ) when compared to 30 barley-infecting populations from different continents (Zaffarano et al. 2006). Findings of high population subdivision and a low number of shared alleles between barley- and rye-infecting populations, as well as an abundance of private alleles in the rye-infecting population, were interpreted as evidence for genetic isolation between the host populations despite the geographical proximity of the two hosts in Switzerland (Zaffarano et al. 2006). Later work with multilocus sequence analyses further suggested that rye/triticale-infecting as well as Agropyron-infecting populations represented species distinct from $R$. secalis, which likely originated by genetic divergence due to host specialization (Zaffarano et al. 2008, 2009). This idea was corroborated by a microsatellite study showing that 13 of the 14 loci developed with a barley-infecting strain of Rhynchosporium could be amplified in Rhynchosporium populations infecting rye, whereas only nine of the 14 loci could be amplified in Agropyron-infecting populations (C.C. Linde unpubl). Finally host specialization of rye-, barley- and Agropyron-infecting Rhynchosporium isolates was demonstrated by cross-infection studies (Zaffarano et al. 2008). Together these findings suggested that $R$. secalis is composed of three cryptic species.

Here we propose that more than two species of Rhynchosporium, specialized on different hosts, can be distinguished. We summarize previously published 
evidence from studies based on pathogenicity, population genetics and multilocus phylogenetic analyses. Species descriptions of two new species of Rhynchosporium are provided.

\section{MATERIALS AND METHODS}

Fungal isolates and molecular analyses.-Sequence data comprised the sequences of isolates from hosts used in our earlier phylogenetic studies and included eight loci: the four housekeeping genes ITS, translation elongation factor 1 alpha $(\mathrm{EF}-1 \alpha), \alpha$-tubulin and $\beta$-tubulin, as reported in Zaffarano et al. (2008), as well as the two non-coding nuclear RFLP loci, pRS6 and pRS52, and parts of the MAT1-1 and MAT1-2 idiomorphs of the mating-type locus (Zaffarano et al. 2009). The total number of isolates from different hosts was Rhynchosporium isolates infecting cultivated barley $(\mathrm{n}=586)$, Hordeum leporinum $(\mathrm{n}=37)$, Hordeum murinum $(\mathrm{n}=9)$, Hordeum spontaneum $(\mathrm{n}=12)$, Bromus diandrus $(\mathrm{n}=2)$, rye $(\mathrm{n}=76)$, triticale $(\mathrm{n}=28)$, Agropyron repens $(\mathrm{n}=66)$, Agropyron caninum $(\mathrm{n}=1)$ and Dactylis glomerata $(\mathrm{n}=13)$. These isolates originated from more than 65 sites on five continents. Detailed descriptions of isolate origins, DNA extraction and sequencing methods were provided by Zaffarano et al. (2008, 2009).

The number of polymorphisms that were fixed between host-infecting populations was calculated for all eight sequence loci with the program DnaSP 4.0 (Rozas et al. 2003). A Bayesian maximum likelihood tree was constructed in MrBayes 3.0b4 (Ronquist and Huelsenbeck 2003) based on a three-gene dataset ( $\alpha$-tubulin and $\beta$-tubulin, ITS; 3066 bp total concatenated sequence length) to represent evolutionary relationships among Rhynchosporium strains isolated from hosts. For this analysis identical DNA sequences were assigned to haplotypes and redundant sequences removed. Details of the analysis are given in Zaffarano et al. (2008), and GenBank accession numbers are HM627410 HM627427 for $\alpha$-tubulin, HM627428-HM627452 for $\beta$ tubulin and HM627468-HM627492 for ITS.

RFLP-PCR screening for species identification.-A RFLP-PCR method for differentiating species was developed based on the ITS locus. A subsample of 22 isolates representing groups infecting barley, rye and triticale was used to evaluate this assay. Isolation and culturing of fungal isolates as well as DNA extraction were as described in McDonald et al. (1999) and Zaffarano et al. (2008). ITS regions were amplified with PCR primers ITS4 and ITS5 (White et al. 1990). PCR reactions were carried out in $20 \mu \mathrm{L}$ volumes containing $2 \mu \mathrm{L} 10 \times$ PCR buffer, $0.1 \mathrm{mM}$ each dNTP, $0.5 \mu \mathrm{M}$ each primer, $0.5 \mathrm{U}$ Taq polymerase (New England BioLabs, Allschwil, Switzerland) and $5 \mu \mathrm{L}$ genomic DNA (5-20 ng final DNA concentration). PCR conditions consisted of a denaturing step at $96 \mathrm{C}$ for $2 \mathrm{~min}$, followed by 35 cycles at $96 \mathrm{C}$ for $1 \mathrm{~min}, 55 \mathrm{C}$ for $1 \mathrm{~min}$ and $72 \mathrm{C}$ for $1 \mathrm{~min}$. Finally a 5 min PCR extension was carried out at $72 \mathrm{C}$.

Restriction enzyme reactions were carried out in a volume of $20 \mu \mathrm{L}$ that contained $2 \mu \mathrm{L} 10 \times \mathrm{T}$ Buffer (Amersham Biosciences), $2 \mu \mathrm{L} 0.01 \%$ BSA (Amersham Biotech), $1 \mathrm{U}$ enzyme SmaI (Amersham Biosciences) and $5 \mu \mathrm{L}$ PCR product. The reaction was incubated at $30 \mathrm{C}$ in a thermocycler $1 \mathrm{~h}$ and chilled on ice. Fragments were separated on a $1.5 \%$ agarose gel containing ethidium bromide and viewed on a UV transilluminator.

\section{RESULTS}

Phylogenetic analyses.-DNA sequences of $\alpha$-tubulin, $\beta$-tubulin and ITS obtained from 316 Rhynchosporium isolates were concatenated and collapsed into 45 haplotypes (H1-H45) to construct a Bayesian maximum likelihood tree. The multilocus phylogenetic analyses (FIG. 1) resulted in Rhynchosporium secalis being divided into three host-associated clades with strong Bayesian posterior probability support (FIG. 1). The first clade of $R$. secalis consisted of haplotypes from barley and other Hordeum species as well as Bromus diandrus and hereafter will be referred to as Rhynchosporium commune Zaffarano, McDonald and Linde sp. nov. The second clade consisted of $R$. secalis from rye and triticale, and the third clade consisted of haplotypes from two Agropyron species, hereafter referred to as Rhynchosporium agropyri Zaffarano, McDonald and Linde sp. nov. All three sequence loci could distinguish among $R$. secalis, $R$. commune and $R$. agropyri. The total number of fixed sequence differences between these species was $0.75-1.39 \%$ based on the eight sequence loci (TABLE I).

PCR-RFLP. - The PCR-RFLP assay could differentiate isolates associated with rye and triticale from all other isolates tested associated with barley (FIG. 2). The C-T transition at position 332 in the ITS region resulted in the absence of a $S m a I$ restriction site in isolates from barley, Hordeum spp., Bromus diandrus and Agropyron spp. A subsample of 22 isolates was used to evaluate the assay. The two predicted PCR-RFLP phenotypes could be distinguished on an agarose gel (FIG. 2), indicating that this assay provides a simple and rapid diagnostic tool to distinguish between the barley- and rye/triticale-infecting species.

\section{TAXONOMY}

Rhynchosporium commune Zaffarano, McDonald and Linde sp. nov. $\quad$ FIG. 1 = Rhynchosporium secalis sensu Oudemans (1897), Davis (1921).

MycoBank MB515024.

Etymology: Latin "commune" = common, referring to the Rhynchosporium species that is most abundant due to large global acreage planted to cultivated barley.

Typus: Switzerland, Cugy, Canton Vaud, isolated from Hordeum vulgare leaves, 1999. Live culture RS99CH6-C1a = ETH ZT Myc2338. 


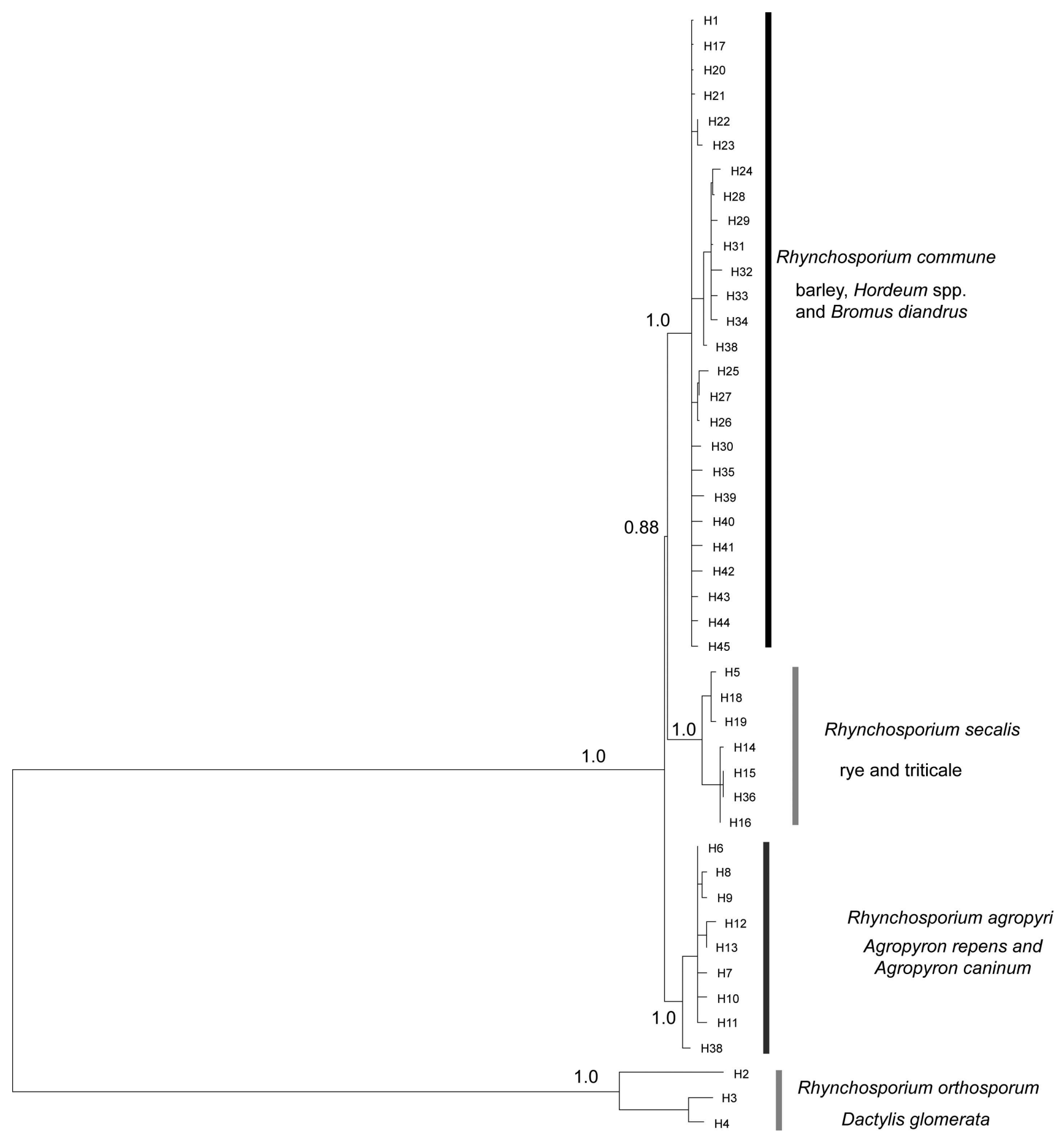

-0.001 substitutions/site

FIG. 1. Multilocus phylogeny inferred by Bayesian maximum likelihood with the haplotype sequences H1-H45 obtained after combining DNA sequences of $\alpha$-tubulin (GenBank accession numbers HM627410-HM627427), $\beta$-tubulin (HM627428HM627452) and ITS (HM627468-HM627492) (Zaffarano et al. 2008). Bayesian posterior probabilities supporting the topology are shown above branches. The tree was rooted with Rhynchosporium orthosporum. The four monophyletic groups represent populations of host-specialized Rhynchosporium spp. (Zaffarano et al. 2008) on cereals and grasses. 
TABLE I. Number of fixed sequence differences (NF) in eight sequence loci between Rhynchosporium lineages on rye, barley, Agropyron repens and Dactylis glomerata. n.a. = data not available for analysis

\begin{tabular}{|c|c|c|c|c|c|c|c|c|c|c|}
\hline \multirow[b]{2}{*}{ Sequence length } & \multicolumn{9}{|c|}{ Locus } & \multirow[b]{2}{*}{$\mathrm{NF} / \mathrm{bp}$} \\
\hline & $\begin{array}{c}\alpha \text {-tubulin } \\
1609 \mathrm{bp}\end{array}$ & $\begin{array}{c}\beta \text {-tubulin } \\
609 \mathrm{bp}\end{array}$ & $\begin{array}{c}\text { Ef- } 1 \alpha^{a} \\
365 \text { bp }\end{array}$ & $\begin{array}{c}\text { ITS }^{\mathrm{a}} \\
848 \mathrm{bp}\end{array}$ & $\begin{array}{c}M A T 1-1^{\mathrm{b}} \\
709 \mathrm{bp}\end{array}$ & $\begin{array}{c}M A T 1-2^{\mathrm{b}} \\
695 \mathrm{bp}\end{array}$ & $\begin{array}{l}\text { pRS52 } \\
1272 \mathrm{bp}\end{array}$ & $\begin{array}{c}\mathrm{pRS}^{\mathrm{b}} \\
1355 \mathrm{bp}\end{array}$ & $\begin{array}{c}\text { Total } \\
7462 \text { bp }\end{array}$ & \\
\hline Barley vs. rye & 1 & 2 & 2 & 9 & 7 & 4 & 11 & 20 & 56 & 0.0075 \\
\hline Barley vs. A. repens & 3 & 4 & 2 & 5 & n.a. & n.a. & 28 & 19 & 61 & 0.0101 \\
\hline Rye vs. A. repens & 4 & 2 & 4 & 10 & n.a. & n.a. & 56 & 8 & 84 & 0.0139 \\
\hline $\begin{array}{l}\text { Barley vs. } D . \\
\text { glomerata } \\
\text { Rye vs. } D .\end{array}$ & 158 & 88 & 78 & 45 & n.a. & n.a. & n.a. & n.a. & 369 & 0.1075 \\
\hline $\begin{array}{l}\text { glomerata } \\
\text { A. repens vs. } D . \\
\text { glomerata }\end{array}$ & 157 & 88 & 80 & 50 & n.a. & n.a. & n.a. & n.a. & 375 & 0.1093 \\
\hline
\end{tabular}

${ }^{\text {a }}$ Zaffarano et al. 2008.

${ }^{\text {b }}$ Zaffarano et al. 2009.

Morphologia idem ac Rhynchosporium secalis sed distinguibilis characteribus sequentibus nucleotidicis fixationibus: alpha tubulinum positio 489 (A); beta tubulinum positiones $241(\mathrm{~T}), 427(\mathrm{~A})$; internal transcribed spacer positiones $116(\mathrm{C}), 304(\mathrm{~T}), 313(\mathrm{G}), 320(\mathrm{C}) ; 332(\mathrm{~T}) ; 420$ (C); 441 (T); 715 (G); 814 (C). PCR amplificatio nucleotidum cum PCR-ITS4 et PCR-ITS5 (White et al. 1990) et subsequenti digestione differt ab hac specie thymina in positione 332 locum restrictionis enzymatis SmaI non formanti et vocato fragmenta duo 332 fasciarum et 516 fasciarum non praebens. Ab hac specie differt: in gramina Hordeum vulgare et Hordeum glaucum et Hordeum leporinum et Hordeum murinum et Hordeum spontaneum et Bromus diandrus, non item Secale cereale, $\times$ Triticosecale, Agropyron repens, Agropyron caninum.

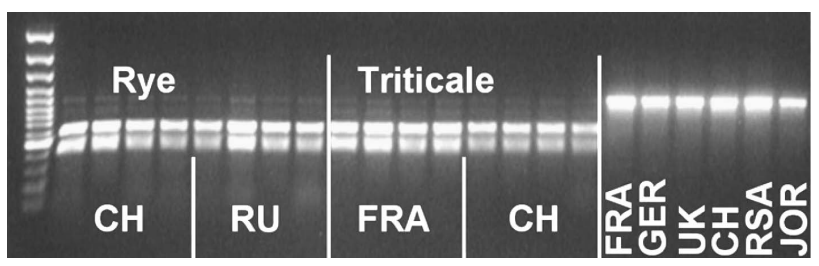

FIG. 2. PCR-RFLP diagnostic assay based on the ITS region of the rDNA gene cluster. The ITS sequence was amplified from a subset of the collection of 316 Rhynchosporium secalis isolates used in Zaffarano et al. (2008). The ITS sequence was digested with SmaI. The first eight isolates were from rye and the following eight from triticale. The last six isolates are from barley. A $100 \mathrm{bp}$ size ladder is shown on the left. The rye-infecting isolates from Switzerland $(\mathrm{CH})$ and Russia (RU), as well as the isolates from triticale from France (FRA) and Switzerland $(\mathrm{CH})$ had a conserved restriction site for SmaI resulting in two fragments of the ITS region that can be separated on a gel. The isolates from barley from France (FRA), Germany (GER), UK, Switzerland (CH), South Africa (RSA) and Jordan (JOR) lacked the restriction site.
Rhynchosporium commune is morphologically indistinguishable from Rhynchosporium secalis but is diagnosed by the following fixed nucleotide differences (presented as the gene and the nucleotide characters fixed in Rhynchosporium commune in parenthesis) between Rhynchosporium commune and Rhynchosporium secalis: alpha tubulin position 489 (A); beta tubulin positions 241 (T), 427 (A); internal transcribed spacer positions $116(\mathrm{C}), 304(\mathrm{~T}), 313$ (G), 320 (C); 332 (T); 420 (C); 441 (T); 715 (G); 814 (C). PCR amplification with primers PCR-ITS4 and PCR-ITS5 (White et al. 1990) followed by digestion with SmaI differs from this species by a thymine (T) at position 332 of the locus and by the absence of the restriction site, which does not yield two fragments, one of 332 base pairs and of 516 base pairs. The species causes infection on Hordeum vulgare, Hordeum glaucum, Hordeum leporinum, Hordeum murinum, Hordeum spontaneum and Bromus diandrus but not on Secale cereale, Agropyron repens, Agropyron caninum.

Rhynchosporium agropyri Zaffarano, McDonald and Linde sp. nov. $\quad$ FIG. 1

= Rhynchosporium secalis sensu Oudemans (1897), Davis (1921).

MycoBank MB515025

Etymology: Referring to the host genus (i.e. Agropyron).

Typus: Switzerland, Zürich, Käferberg, isolated from Agropyon repens leaves, 2004. Live culture RS04CH-Käferberg-4-1A4.1 = ETH ZT Myc2337

Morphologia idem ac Rhynchosporium secalis sed distinguibilis characteribus sequentibus nucleotidicis fixationibus: alpha tubulinum positiones 93 (T), 335 (G), 489 (G); 
748 (A); beta tubulinum positiones 296 (A), 566 (A); internal transcribed spacer positiones $251(\mathrm{C}) ; 304(\mathrm{~T}) ; 313$ (G); $321(\mathrm{G}) ; 332(\mathrm{~T}) ; 441(\mathrm{~T}) ; 715(\mathrm{G}) ; 814(\mathrm{C}) ; 826(\mathrm{C})$. PCR amplificatio nucleotidum cum PCR-ITS4 et PCR-ITS5 (White et al. 1990) et subsequenti digestione differt ab hac specie thymina in positione 332 locum restrictionis enzymatis SmaI non formanti et vocato fragmenta duo 332 fasciarum et 516 fasciarum non praebens. Ab hac specie differt: in gramina Agropyron repens et Agropyron caninum, non item Secale cereale, $\times$ Triticosecale, Hordeum vulgare, Hordeum glaucum, Hordeum leporinum, Hordeum murinum, Hordeum spontaneum, Bromus diandrus.

Rhynchosporium agropyri is morphologically indistinguishable from Rhynchosporium secalis but is diagnosed by the following fixed nucleotide differences (presented as the gene and the nucleotide characters fixed in Rhynchosporium agropyri in parenthesis) between Rhynchosporium commune and Rhynchosporium secalis: alpha tubulin positions 93 (T), $335(\mathrm{G}), 489(\mathrm{G})$; $748(\mathrm{~A})$; beta tubulin positions 296 (A), 566 (A); internal transcribed spacer positions $251(\mathrm{C}) ; 304(\mathrm{~T}) ; 313(\mathrm{G}) ; 321(\mathrm{G}) ; 332(\mathrm{~T}) ; 441$ (T); $715(\mathrm{G}) ; 814(\mathrm{C}) ; 826(\mathrm{C})$. PCR amplification with primers PCR-ITS4 and PCR-ITS5 (White et al. 1990) followed by digestion with SmaI differs from this species by a thymine (T) at position 332 of the locus and by the absence of the restriction site that does not yield two fragments, one of 332 base pairs and of 516 base pairs. The species causes infection on Agropyron repens and Agropyron caninum but not on Hordeum vulgare, Hordeum glaucum, Hordeum leporinum, Hordeum murinum, Hordeum spontaneum, Bromus diandrus and Secale cereale.

DISCUSSION

Host specialization as inferred by pathogenicity studies.-Host specialization can cause reproductive isolation between fungal populations eventually leading to speciation. Although the pathogen originally was described from rye and also infects triticale and other grasses, most virulence studies have been conducted with $R$. secalis infecting barley and applied exclusively to barley because of the economical importance of this crop. Notably fewer studies were devoted to testing pathogenicity of $R$. secalis on different hosts. In such studies, instead of addressing species concepts, plant pathologists focused on the epidemiology of the pathogen on barley and aimed at identifying potential sources of inoculum originating from alternative hosts. Earlier studies included relatively few isolates and used varying inoculum concentrations and different environmental conditions. This makes comparisons difficult, but given our recent findings we consider it useful to review these pathogenicity studies conducted over almost a century.
Bartels (1928) and Heinsen (1901) reported no specialization on rye and barley in Germany. In contrast Müller (1957) used one Swiss isolate, either from barley or rye, to inoculate more than a hundred plants of each host and did not detect cross infection, consistent with Caldwell's results (1937) in the greenhouse and in the field in USA. Caldwell (1937) obtained one barley-infecting isolate from Germany that apparently was used in Bartel's (1928) study. In contrast to Bartel Caldwell was not successful in infecting rye with this isolate. Many other studies were unable to achieve symptoms on barley and rye after cross infection (e.g. Sarasola and Campi 1947, Owen 1958, Kajiwara 1968, Ali and Boyd 1973, Jackson and Webster 1976, Cromey and Mulholland 1987, Robinson et al. 1996). Lebedeva and Tvarǔžek (2006) conducted a large pathogenicity study with 55 isolates from barley and 34 isolates from rye collected in Russia and the Czech Republic. Mixtures of isolates from each host were inoculated onto 10 rye and 10 triticale varieties and onto one susceptible barley variety. Strict host specialization was observed and the rye-infecting isolates were not able to infect triticale despite the genetic proximity of these two crops.

In contrast Jørgensen and Smedegard-Petersen (1995) reported small lesions after cross inoculations on barley and rye were made in Denmark, although the plants were considered to be resistant. Kay and Owen (1973) found no infection on rye with 27 barley-infecting isolates while five rye-infecting isolates infected barley in UK. One of these isolates produced lesions on barley without the typical dark margin that is normally present on barley but absent on rye. Kilby and Robinson (2001) similarly reported that one Finnish rye isolate infected susceptible barley varieties and was even more virulent on barley than some of the tested isolates from barley.

Uncultivated grass hosts of Rhynchosporium are part of the natural flora and often found in pastures. They also are found along roadsides and are common weeds of cereal fields that can be transported in hay. Thus frequent gene flow of Rhynchosporium populations from these grasses onto cultivated hosts and vice versa is possible. In fact isolates from barley and its closely related Hordeum spp. show little specialization (Bartels 1928, Caldwell 1937, Owen 1958, Kay and Owen 1973, Brown 1990, Kiros-Meles et al. 2010), although there is some evidence for specific resistance genes. Cromey and Mulholland (1987) produced symptoms on barley with isolates from Hordeum murinum but not on $H$. murinum with isolates from barley. In Australia isolates from $H$. leporinum infected cultivated barley (C.C. Linde unpubl). Inconsistent findings related to host spe- 
cialization were found for Rhynchosporium infecting the host genus Bromus (Bartels 1928, Caldwell 1937, Schein 1958, Christensen and Wilcoxson 1959, Ali and Boyd 1973, Jackson and Webster 1976) and the host genus Agropyron (Bartels 1928, Smith 1937, Caldwell 1937, Schein 1958, Ali and Boyd 1973, Jackson and Webster 1976).

In these studies the full range of strict, little or no host specialization was demonstrated. The limited numbers of isolates from hosts other than barley, the different conditions under which the tests were performed and the different ways used to classify the symptoms make a comparison of all these studies difficult. For example Ali and Boyd (1973) were able to infect hosts in a greenhouse that were not susceptible in the field or were not the usual hosts of Rhynchosporium (e.g. wheat), although the degree of infection was limited. We agree with Shipton's statement (1974) that "exceptions to such specialization may be artifacts of the environmental conditions prevailing and of academic rather than economic consequence under field conditions. Spore concentrations used in artificial inoculation studies are often considerably greater than those occurring in the field." It is difficult to assess the relevance of the reported cases of exceptions to host specialization in the framework of species definitions.

Molecular genetic techniques such as DNA sequencing have helped elucidate species boundaries in fungi that are morphologically indistinguishable by applying the phylogenetic species concept (PSC) (reviewed in Taylor et al. 2000) and can be used to test the hypothesis of host-driven speciation in $R$. secalis. The main advantage of the PSC over the morphological species concept (MSC) and the biological species concept (BSC) (Mayden 1997, Taylor et al. 2000) is that changes in gene sequences leading to new species formation can be detected long before differences in morphology or mating behavior become evident. It often is not possible to apply the BSC, especially for the many fungi that do not have a known sexual stage. $R$. secalis is believed to be asexual, although indirect evidence for sexual reproduction has been shown (Linde et al. 2003, Zaffarano et al. 2006). The teleomorph has never been induced in vitro or observed in the field. Several studies have successfully detected cryptic fungal species by genealogical concordance (as reported in Taylor et al. 2000) and other parasite groups also have been found to comprise species complexes following the PSC (Lymbery and Thompson 1996, Hung et al. 1999, Perkins 2000).

Our phylogenetic study confirms that Rhynchosporium isolates infecting cultivated barley, $H$. leporinum, $H$. spontaneum, $H$. murinum and B. diandrus, belong to the same species. In our phylogenetic analyses the haplotypes from uncultivated Hordeum were shared with isolates from cultivated barley. Only a few isolates from H. leporinum and Hordeum murinum and the two from Bromus diandrus formed unique haplotypes that were not shared with isolates from other hosts. Nevertheless these haplotypes were placed in the same phylogenetic clade with the haplotypes representing the barley-infecting isolates for all three gene sequences. We also analyzed isolates from $H$. leporinum and B. diandrus from Australia with RFLPs, as well as from $H$. spontaneum from the Middle East (Zaffarano et al. 2006) and could not identify any genetic differentiation among these isolates and isolates from cultivated barley collected in the same regions.

Speciation and its practical aspects.-In many of the earlier pathogenicity studies it is not clear how the inoculum was produced, what spore concentrations were applied, how many host plants were inoculated and how many of these were infected (e.g. Heinsen 1901, Bartels 1928, Caldwell 1937, Smith 1939) and why certain isolates did not even infect their original host (e.g. Kay and Owen 1973, Owen 1958). We previously conducted greenhouse-based pathogenicity studies on barley, rye and $H$. murinum with a subset of the isolates that were included in the phylogenetic analysis. These 15 isolates were from barley, rye, triticale, $H$. murinum and A. repens (Zaffarano et al. 2008). No cross infections were detected except for isolates from $H$. murinum on barley cultivars and the isolate from triticale on rye. As discussed previously the great majority of published pathogenicity studies on rye and barley showed host specialization and were consistent with our findings based on population genetic and phylogenetic analyses, as well as with our pathogenicity tests (Zaffarano et al. 2008), which all showed host-specific delimitation of the pathogen on rye, barley and Agropyron spp.

If genetic variation in barley-infecting $R$. secalis populations is influenced by gene flow from alternative hosts, the efficiency of barley breeding programs could be affected if isolates from alternative hosts are not included in resistance screening. This concern has been reinforced by findings that $R$. secalis populations from barley, rye (Schürch et al. 2004, Kilby and Robinson 2001) and A. repens (Kilby and Robinson 2001) share the avirulence gene NIP1, which most likely arose before species differentiation. Our molecular and phenotypic data indicate that no genetic exchange occurs among these host-specialized populations. The crop triticale $(\times$ Triticosecale Wittmack) resulted from hybridizing wheat (Triticum aestivum L.) with rye (Secale cereale L.). Triticale is of 
recent origin and was commercialized at the end of the 1960s (Ammar et al. 2004, Oettler 2005). We infected rye with a Swiss isolate from triticale, confirming results from Welty and Metzger (1996) who used a triticale-infecting isolate to cross infect rye in USA. Although Rhynchosporium occurs on triticale, only a few reports have been recorded (reviewed in Welty and Metzger 1996). The paucity of scald reports might mean that the disease is still not broadly spread on triticale, perhaps because triticale is not cultivated on the same acreage as for example barley. Susceptibility in triticale could have occurred due to the loss of scald resistance in the genome supplied by the wheat parent or because new pathogenic forms of Rhynchosporium have emerged recently (Welty and Metzger 1996). However the phylogenetic and coalescent analyses (Zaffarano et al. 2008) suggest that rye- and triticale-infecting isolates belong to the same gene pool and thus share the same origin.

Species or formae speciales?-Forma specialis is a taxonomic case used often in plant pathology to describe a pathogen specialized to a specific host. It could be argued that the strict host specialization observed in this study presents a case where formae speciales should be applied. But we have several lines of evidence to support new species names: (i) the Rhynchosporium isolates separate into three well supported monophyletic clades across an array of eight genes; (ii) these clades are associated with different hosts; (iii) a significant number of fixed sequence differences $(0.75-1.39 \%$ of all base pairs in the analysis) were found between the host-associated lineages; (iv) geographically proximate populations on different hosts show a high degree of population differentiation for SSR and RFLP markers. Taken together these findings indicate that the three clades are not populations within the same species that have diverged. Instead they are distinct species. Similar arguments have been applied to define species for other fungal pathogens infecting grasses (e.g. Couch and Kohn 2002) and for common root-associated fungi (Grünig et al. 2008).

In summary a combination of population genetic, phylogenetic and phytopathological analyses let us resolve approximately $100 \mathrm{y}$ of ambiguous findings regarding the nature of host specialization in $R$. secalis. We think that these closely related Rhynchosporium species emerged during the past few thousand years through a speciation process driven by host specialization. Thus we anticipate that a comparison of entire genome sequences in these species might let us identify genes involved in host specialization and speciation.

\section{LITERATURE CITED}

Ali SM. 1981. Barley grass as a source of pathogenic variation in Rhynchosporium secalis. Aus J Agric Res 32:21-25, doi:10.1071/AR9810021

—_ Boyd WJR. 1973. Host range and physiologic specialization in Rhynchosporium secalis. Aus J Agric Res 25:21-31, doi:10.1071/AR9740021

Ammar K, Mergoum M, Rajaram S. 2004. The history and evolution of triticale. In: Triticale improvement and production. FAO Plant Production and Protection Paper 179:1-9.

Bartels F. 1928. Studien über Marssonina graminicola. Forsch Geb Pflanzenkrankh U Immun Pflanzenreich 5:73-114.

Brown JS. 1990. Pathogenic variation among isolates of Rhynchosporium secalis from barley grass growing in south eastern Australia. Euphytica 50:81-89, doi:10. $1007 /$ BF00023164

Caldwell RM. 1937. Rhynchosporium scald of barley, rye and other grasses. J Agric Res 55:175-198.

Christensen EV, Wilcoxson RD. 1959. Factors affecting the development of Rhynchosporium scald on brome grass. Phytopathology 49:323-396.

Couch BC, Kohn LM. 2002. A multilocus gene genealogy concordant with host preference indicates segregation of a new species, Magnaporthe oryzae, from M. grisea. Mycologia 94:683-693, doi:10.2307/3761719

Cromey MG, Mulholland RI. 1987. Host specialization of Rhynchosporium secalis in New Zealand. NZ J Agric Res 30:345-348.

Davis JJ. 1919. Notes on parasitic fungi in Wisconsin. Trans Wis Acad Sci Arts Lett 19:705-727.

- 1921. Notes on parasitic fungi in Wisconsin. Trans Wis Acad Sci Arts Lett 20:413-431.

Foster SJ, Fitt BDL. 2004. Isolation and characterization oft he mating-type (MAT) locus from Rhynchosporium secalis. Curr Genet 44:277-286, doi:10.1007/s00294-003-0445-9

Frank AB. 1897. Über die Zerstörung der Gerste durch einen neuen Getreide-Pilz. Wochenschrift Brauerei 14: 518-520.

Goodwin SB. 2002. The barley scald pathogen Rhynchosporium secalis is closely related to the discomycetes Tapesia and Pyrenopeziza. Myc Res 106:645-654, doi:10.1017/ S0953756202006007

Grünig CR, Duo A, Sieber TN, Holdenrieder O. 2008. Assignment of species rank to six reproductively isolated cryptic species of the Phialocephala fortinii s.l.-Acephala applanata species complex. Mycologia 100:47-67, doi:10.3852/mycologia.100.1.47

Heinsen E. 1901. Beobachtungen über den Getreidepilz Rhynchosporium graminicola. Jahrb Hamburg Wiss Anst 18:45-55.

Hung GC, Chilton NB, Beveridge I, Zhu XQ, Lichtenfels JR, Gasser RB. 1999. Molecular evidence for cryptic species within Cylicostephanus minutus (Nematoda, Strongylidae). Int J Parasitol 29:285-291, doi:10.1016/ S0020-7519(98) 00203-3

Jackson LF, Webster RK. 1976. Seed and grasses as possible 
sources of Rhynchosporium secalis for barley in California. Plant Dis Rep 60:233-236.

Jørgensen HJ, Smedegaard-Petersen V. 1995. Pathogenic variation of Rhynchosporium secalis in Denmark and sources of resistance in barley. Plant Dis 79:297-301, doi:10.1094/PD-79-0297

Kajiwara T. 1968. Comparative studies on the pathogenicity of barley and rye scald fungus, Rhynchosporium secalis (Oud.) Davis. Bull Nat Inst Agr Sci, Ser. C No. 22.

Kay JG, Owen H. 1973. Host range of Rhynchosporium secalis. Trans Br Mycol Soc 60:413-422, doi:10.1016/ S0007-1536(73) 80026-9

Kilby NJ, Robinson J. 2001. Pathotypes and NIP1 gene sequences of Finnish Rhynchosporium secalis isolates from barley, couch grass and rye. Euphytica 120:265272, doi:10.1023/A:1017574631186

Kiros-Meles A, Gomez D, Yahyaoui A, McDonald BA, Linde CC. 2010. Invasion of Rhynchosporium commune onto wild barley in the Middle East. Biol Invasions. (In press).

Lebedeva L, Tvarůžek L. 2006. Specialisation of Rhynchosporium secalis (Oud.) J.J. Davis Infecting Barley and Rye. Plant Prot Sci 42:85-93.

Linde CC, Zala M, Ceccarelli S, McDonald BA. 2003. Further evidence for sexual reproduction in Rhynchosporium secalis based on distribution and frequency of mating-type alleles. Fungal Genet Biol 40:115-125, doi:10.1016/S1087-1845(03)00110-5

Lymbery AJ, Thompson RCA. 1996. Species of Echinococcus: pattern and process. Parasitol Today 12:486-491, doi:10.1016/S0169-4758(96)10071-5

Mayden RL. 1997. A hierarchy of species concepts: the denouement in the saga of the species problem. In: Claridge MF, Dawah HA, Wilson MR, eds. Species: the units of biodiversity. London: Chapman \& Hall Ltd. p 381-424.

McDonald BA, Zhan J, Burdon JJ. 1999. Genetic structure of Rhynchosporium secalis in Australia. Phytopathology 89: 639-645, doi:10.1094/РНYTO.1999.89.8.639

Müller E. 1957. Versuche mit Rhynchosporium-Schorf von Gerste und Roggen. Annu Agric Suisse 2:739-743.

Oettler G. 2005. The fortune of a botanical curiosityTriticale: past, present and future. J Agric Sci 143:329346, doi:10.1017/S0021859605005290

Oudemans CAJA. 1897. Observations mycologiques. K. Akad. Wetensch. Amsterdam Verslag. Wis en Natuurk Afd 6:86-92.

Owen H. 1958. Physiologic specialization in Rhynchosporium secalis. Trans Br Mycol Soc 41:99-108, doi:10.1016/ S0007-1536(58) 80013-3

Perkins S. 2000. Species concepts and malaria parasites: detecting a cryptic species of Plasmodium. Proc Roy Soc London B 267:2345-2350, doi:10.1098/rspb.2000.1290

Robinson J, Lindqvist H, Jalli M. 1996. Genes for resistance in barley to Finnish isolates of Rhynchosporium secalis. Euphytica 92:295-300, doi:10.1007/BF00037111

Ronquist F, Huelsenbeck JP. 2003. MrBayes 3: Bayesian phylogenetic inference under mixed models. Bioinformatics 19:1572-1574, doi:10.1093/bioinformatics/ btg 180

Rozas J, Sanchez-DelBarrio JC, Messeguer X, Rozas R. 2003. DnaSP, DNA polymorphism analyses by the coalescent and other methods. Bioinformatics 19:2496-2497, doi:10.1093/bioinformatics/btg359

Sarasola JA, Campi MD. 1947. Reaccion de algunas cebadas con respecto a Rhynchosporium secalis en Argentina. Rev Invest Agric I Nr 4:243-260.

Schein RD. 1958. Pathogenic specialization in Rhynchosporium secalis. Phytopathology 48:477-480.

Schürch S, Linde CC, Knogge W, Jackson L, McDonald BA. 2004. Molecular population genetic analysis differentiates two virulence mechanisms of the fungal avirulence gene NIP1. Mol Plant Microbe Interact 17:1114-1125, doi:10.1094/MPMI.2004.17.10.1114

Shipton WA. 1974. Scald of barley. Rev Plant Pathol 53:839861.

Smith NJG. 1937. Leaf-scald of barley in South Africa. S Afric J Sci 34:286-290.

Taylor JW, Jacobson DJ, Kroken S, Kasuga T, Geiser DM, Hibbet DS, Fisher MC. 2000. Phylogentic species recognition and species concepts in fungi. Fungal Genet Biol 31:21-32, doi:10.1006/fgbi.2000.1228

Welty RE, Metzger RJ. 1996. First report of scald of triticale caused by Rhynchosporium secalis in North America. Plant Dis 80:1220-1223, doi:10.1094/PD-80-1220

White TJ, Bruns T, Lee S, Taylor J. 1990. Amplification and direct sequencing of fungal ribosomal RNA genes for phylogenetics. In: Innis MA, Gelfand DH, Sninsky JJ, White TJ, eds. PCR protocols: a guide to methods and applications. San Diego: Academic Press. p 315-322.

Zaffarano PL, McDonald BA, Linde CC. 2009. Phylogeographical analyses reveal global migration patterns of the barley scald pathogen Rhynchosporium secalis. Mol Ecol 18:279-293, doi:10.1111/j.1365-294X.2008.04013.x

, — Z Zala M, Linde CC. 2006. Global hierarchical gene diversity analysis suggests the Fertile Crescent is not the center of origin of the barley scald pathogen Rhynchosporium secalis. Phytopathology 96:941-950, doi:10.1094/PHYTO-96-0941

$-\longrightarrow,-\longrightarrow$, 2008. Rapid speciation following recent host shifts in the plant pathogenic fungus Rhynchosporium. Evolution 62:1418-1436, doi:10.1111/j.1558-5646.2008.00390.x 